Original Article

\title{
The costs of globalization: Producing new forms of risk to health and well-being
}

\author{
Ray Hudson \\ Department of Geography, Durham University, Science Laboratories, \\ South Road, Durham DH1 3LE, UK. \\ E-mail: ray.hudson@durham.ac.uk
}

\begin{abstract}
Processes of contemporary globalization generate a particular landscape of risk. This landscape is shaped by the economic imperatives that lead to the export of hazardous activities, processes and materials in combination with the uneven regulatory spaces within which these activities are placed. The perceptible neo-liberal shift in the regulation of economies has resulted in considerable emphasis on 'freeing up' of market forces nationally and opening national and sub-national economies and labour markets to the disciplining forces of international markets. These are changes with direct consequences in terms of enhanced risks to the health and well-being of millions of people, although their effects have been experienced to differing degrees in different parts of the world. This paper explores these issues and raises questions about the long-term implications that these shifts may have for public health risk, especially in recently developing countries and emerging economies.
\end{abstract}

Risk Management (2009) 11, 13-29. doi:10.1057/rm.2008.13

Keywords: globalization; health and well-being; environmental pollution; hazard and risk; economic geographies; uneven development; spaces of regulation; neo-liberalism

\section{Introduction}

7 he globalization of hazard has become an important issue since the early 1980s when it first came to media prominence through the

transfers of hazardous wastes. Since then, the 'export' of risk from the Western economies of the global 'North' to those of the unevenly developing 'South' has continued and the increased pollution from across the globe has led to serious concerns about its impact on climate change. Thus, 
globalization is a double-edged sword in risk terms. Globalization is not, however, a new phenomenon as capitalism from the outset was constituted via processes of combined and uneven development that brought various scattered parts of the globe into systemically unequal relationships with one another. There are numerous accounts of the successive forms of the international division of labour and changing socio-spatial forms of globalization (see, for example, Hirst and Thompson, 1995). Rather our concern here is to focus on the latest neoliberal phase of globalization, its defining features and their implications for the health and well-being of people. Now as then - and despite assertions to the contrary about globalization heralding 'the end of geography' (O'Brien, 1992) - the geography of contemporary globalization remains one of profound combined and uneven development, characterized by sharpened socio-spatial inequalities as the political - economy of neo-liberalism and neo-liberal thought have become increasingly dominant in the policy discourse and practices of the leading national states and international organizations such as the World Bank and International Monetary Fund. The combination of economic factors, the export of hazardous activities, processes and materials, along with the uneven regulatory spaces within which these activities are contextualized generates a landscape of risk that is shaped by the processes of contemporary globalization. The perceptible shift in the regulation of economies towards one constituted within a neo-liberal framework has resulted in a considerable emphasis on the 'freeing up' of market forces nationally and also the opening of national and sub-national economies and labour markets to the disciplining forces of international markets. These are changes with direct consequences in terms of enhanced risks to the health and well-being of many millions of people, although their effects have been experienced to differing degrees in different parts of the world. This paper seeks to explore these issues and to raise questions about the longterm implications that these shifts may have for public health risk, especially in recently developing countries. Before examining these issues in more detail, it is first necessary to examine the facets of contemporary neo-liberal globalization that serve as the driving force behind the generation of these risks.

\section{What's New about Contemporary Neo-Liberal Globalization?}

The net effect of the adoption of neo-liberal policy positions has been that in the course of their daily lives many people live in increasingly risky and unhealthy environments. In addition, they also experience increased risks of unemployment and worklessness and often have to undertake forms of employment that militate against good health and well-being. There are several reasons as to why this is so.

Firstly, and perhaps most importantly, the pre-eminence attached to market forces in general and the forces of global markets in particular as the prime 
mechanism for steering and disciplining economies - whether national, regional or corporate - has been decisive and defining. This, above all else, has enabled the enhanced globalization of capital, which has resulted in the latest phase of combined and uneven development. That said, it is important to appreciate that these are by no means natural market forces but rather a product of the ways in which markets have been politically constructed and regulated, not least by powerful national states. Ironically, it is those nation states that often have the most stringent regulatory frameworks in place for environmental impact and health and safety within their own national territories. The resultant paradox is that the political construction of markets 'at home' may have the effect of generating risky environments abroad.

This greater emphasis on the role of market forces has had a number of consequences, of which three are of significance in this context. Firstly, there has been a significant extension of the commodity form, with two important implications. On the one hand, there has been a redrawing of the boundary between private and public sectors. Expanded commodification has led to the replacement of state provision (of jobs, housing, goods and services) as an entitlement of citizens with provision via markets to customers - not all of whom, of course, are able to afford them. On the other, there has been an extension of the realm of the commodity form into areas of private and community life, and into the sphere of civil society, from which it was previously excluded by customary practices and tradition. These changes have further emphasized the importance for many people of access to waged work in order to gain access to the goods and services central to health and well-being in the course of everyday life. In certain cases, access to waged work is also a means of accessing effective health care provision at a level above that of a 'safety net'. This can either be directly, in terms of access to health care insurance, or indirectly as a function of spatial location (referred to in the United Kingdom as the so-called 'post-code lottery').

Secondly, the restructuring of markets has reduced the predictability and certainty of transactions and introduced greater risk and uncertainty for those reliant on markets for the supply of employment and provision of services. The interconnected nature of these markets and the manner in which a failure in one market can cascade through to others was illustrated by the collapse of the sub-prime market in the United States in 2008 and the impact that it had on bank performance in the United Kingdom (notably that of Northern Rock). Within this highly interconnected context, employment has become increasing precarious and temporary (for example, see Beck, 1992) where before it was secure and long term. In addition to this problem, the spatial inequalities that exist in terms of access to jobs and services have also been amplified.

Thirdly, there has been a growing selective incorporation of these new market principles into the residual public sector, expressed in the erosion of trust and growth of a culture of audit and monitoring. The result is an 
organizational environment in which a number of concerns and problems have emerged. These include, among others, the setting and meeting of targets (many of which do not relate to core service performance); with a range of pseudo-profitability criteria that have been set for public service agencies; and with the reworking of the public - private sector divide so that the qualitative distinction between public and private sector provision has been significantly eroded.

These tendencies have been seen to operate more strongly in some countries than others but few parts of the world have escaped their effects. A defining feature of this development has therefore been the growing influence of markets as allocation mechanisms coupled with the tilting of market forces and laws of contract in favour of employers and selected categories of employees, while increasing the general level of insecurity and risk of job loss for the (much greater) majority. These are changes with important implications for the health and well-being of workers and those people who are dependent on them. This increased emphasis on global market forces has in turn emphasized the critical significance of the competitive strategies of major multinational companies, the deployment of different mixes of 'weak' and 'strong' competitive strategies, often involving new forms of interfirm cooperative relationships and strategic alliances, and the new geographies of production and work that these create via processes of outsourcing and/or offshoring as the pace of capital movement quickens (Hudson, 2001). Over 30 years ago Damette (1974; translated 1980) coined the term 'hypermobility of capital' to describe this accelerating mobility of capital as the turnover time of fixed capital is progressively reduced as capital is written-off and amortized over shorter time periods - a salutary reminder that such processes are by no means new. As a result, the pace at which capital is devalorized in some places and abandons them and penetrates and is fixed in others has accelerated both in the cities and regions of the global 'South' and in parts of the peripheries of the global 'North'. ${ }^{1}$

Accelerated movement of capital in turn has implications for intensified competition between places and workers for waged work and increases the risks of people in a particular place becoming surplus to the requirements of capital. Waged work becomes increasingly precarious, increasing the risks of unemployment and worklessness as jobs disappear from one place to be relocated elsewhere. Given the known close links between work, identity and well-being, this carries obvious risks for those who become redundant in the process. As the economic well-being of a place is eroded, then the ability of governments to fund health and welfare programmes from tax revenues is also impaired. The combination of increased problems of poor health by virtue of joblessness (and the potential for associated issues around environmental quality) and the impairment of healthcare provision is a double blow to such places. 
Issues of environmental quality and its impact on public health, especially linked to the location of noxious and pollutant industrial processes - captured in the phenomenon of NIMBYism and its catchphrase 'Not in my backyard' - have become increasingly significant. In part, these predate the latest phase of globalization as people in more economically developed countries came to understand the dangers posed by noxious pollutants and environmental standards were raised. In response, many polluting industries were relocated to parts of the 'South'. The accident at Bhopal in 1984 was a poignant reminder of the ways in which certain multinational companies also exported hazardous processes as well as products. In this case, the Indian plant was of 'similar' design to that operated in the United States, but the standards of maintenance that were in operation fell far short of those that would be allowed in a highly regulated country. Although Union Carbide was accused of double standards in allowing such a practice in one of its subsidiaries, it managed effectively to deflect much of that blame to its Indian subsidiary. In some cases, the waste products of the 'North', which were expensive to dispose of in a highly regulated environment, were also exported to the 'South'. In addition to the relocation of pollutant and risky processes, however, a second major feature of the neo-liberal era became the growing globalization of wastes flows and new forms of trade in wastes. For example, stringent regulations on recycling were introduced in Germany in the 1990s. Picking through waste to sort and recycle it is labour intensive, poorly paid and of low social esteem. As such, it is exported to peripheral parts of the global economy - and justified as creating employment there! A particularly striking example of the new trade in wastes is the scrapping and recycling of ships on the beaches of Bangladesh (Chittagong; see Buerk, 2006) and India (Alang). Although international regulatory and trade agreements have halted the worst excesses of the trade in noxious wastes, they have failed to stop it. Consequently, the global 'North' still offloads its wastes onto the 'South'. However, the international trade in pollutant materials and wastes is a complex one, with wastes transported to peripheral locations within the 'North'. For example, wastes produced in the steel industry in England and Wales are shipped to Germany and Italy for remediation, nuclear waste has been shipped from Japan to Sellafield in northwest England for reprocessing there and derelict United States and French warships, replete with a variety of noxious substances (including asbestos and polychlorinated biphenols (PCBs); BAN, 2003), have been moved to Hartlepool in northeast England for dismantling and disposal.

Exporting wastes in this way was cheaper than dealing with them at home, and made easier when recipient countries were misled about the nature of the wastes and/or had authoritarian nonelected governments who neither knew nor cared. Perhaps more significantly, dealing with pollutants at home could entail political costs, in the face of NIMBYism and opposition by local communities to wastes being treated in 'their back yard' (Smith, 1991). 
However, local communities have differential capacity to resist, as the examples of Hartlepool and Sellafield illustrate. Nuclear waste has been reprocessed at Sellafield for some 50 years, with persistent worries about the effects of accidents and the exposure of workers and local residents to radiation. However, Sellafield is located in a peripheral region, with few other employment opportunities, as is Hartlepool. This process of noxious activities being located in areas of low economic and political power, and therefore low resistance, is not a new phenomena (see Smith, 1990) and as David Harvey (1996, p. 368) observed,

one of the best predictors of the location of toxic waste dumps in the United States is a geographical concentration of people of low income and color.

Indeed, poorer communities within the 'North' and 'South' have engaged in bidding wars, seeking to become destinations for hazardous wastes in return for monetary payments and incomes. Some countries are so poor, and in such desperate need of foreign currency earnings (to buy imports or repay foreign debt) that ruling élites encourage any trade likely to generate such earnings, discounting risks to the environment and the health of their populations (an issue discussed further below).

The third diagnostic feature of neo-liberal globalization is the increased globalization of corporeal flows, of the movement of people in a variety of roles. These include people moving as international migrant workers with varying levels of qualification in globally segmented labour markets, many as illegal migrants who lead a precarious and deeply exploited existence in their country of destination as a result, as refugees (who typically lack citizenship rights and may also be illegal migrants), and as tourists. There are powerful arguments that processes of time/space compression and convergence have enabled faster, more frequent and more distant flows. Although the vast majority of flows of people remain within national boundaries and over relatively short distances, there has nonetheless been a tremendous growth in movements across national boundaries. For example, in 1950 there were 25 million international passenger arrivals; currently there are over 600 million each year, and the scale of future movements is forecast to increase markedly. The number of international migrants has more than doubled over the period 1965-2000 to 175 million (International Organisation for Migration, 2003). From the perspective of disease transmission, the highly connected nature of contemporary societies has considerable impacts on the spread of diseases, as illustrated by the severe acute respiratory syndrome (SARS) outbreak and the potential that exists for a bird flu pandemic.

The fourth feature of neo-liberal globalization of relevance here is the prevalence of food shortages and famine. This is a process in which many causal factors integrate together in space - time to generate problems. For example, 
food shortages can be in part induced by climate change and in part because of the iniquities of food distribution systems, rather than an absolute shortage of food per se (Sen, 1983). They may also occur in part because of the proliferation of 'failed' or 'fragile states' and in part be a product of the renewed willingness to have recourse to physical violence and war as a way of dealing with political issues. This has led to death and destruction of peoples' lives on a massive scale (as is only too evident from events Afghanistan, Eritrea, Iraq and Zimbabwe), in turn acting as a major cause of refugee flows. There is some debate as to how to define 'failed' or 'fragile' states ${ }^{2}$ but for $\operatorname{DiFD}(2005$, p. 7) 'fragile states' are those in which 'the government cannot or will not deliver core functions to the majority of its people, including the poor'. The phrase 'cannot or will not' is a significant one, sliding over a key difference between those states in which ruling elites could and choose not to deliver core functions such as healthcare and those that are simply too poor in the first place for this to be a feasible possibility. This group of 'failed states' includes but is not limited to those states riven by internal conflict and civil wars, and includes those in which problems of corruption in government lead to the siphoning off of resources from health and health care.

\section{What are the Implications for Increased Risks to Health and Well-being?}

There are a number of issues to address here. Firstly, there is a wealth of well-established evidence that a combination of high psychological work demands, low levels of job task control (in terms of both decision authority and skill utilization) and the perceived (and typically real) risk of job loss leads to increased work related stress and subsequently produces higher rates of psychological and physical morbidity (for example, see Dooley et al, 1987; Muntaner et al, 1998; Benavides et al, 2000; Benach et al, 2002; de Vries et al, 2003; Wegge et al, 2006; Benach and Muntaner, 2007). Although it is difficult to disentangle the effects of job insecurity and more structural features of 'precarious work' from the more general effects of socio-economic status or position (Adler and Newman, 2002), these adverse effects on mental and physical health and well-being have become endemic as competitive pressures have intensified, especially as work has become increasingly precarious and/or intensified in the era of neo-liberal globalization. The 'lean' high-performance, high-volume flexible production (HVFP) plants found in the peripheries of the 'North' often offer the only significant manufacturing employment to be found in these regions. On the positive side, in contrast to Taylorist mass production, HVFP approaches require management of the labour process through employee commitment to and involvement in the job via human resource management and total quality management practices. These are better quality jobs in that there is emphasis on quality enhancement, problem 
solving rather than machine minding and longer job - task cycle times. However, these jobs also bring with them problems as they are often built around (sometimes conflicting) themes such as flexibility, responsibility, selfdevelopment, job enrichment, training, security of employment, performancerelated pay schemes, teamwork and improving the commitment and trust of a more valued workforce. Although many of these facets of HVFP jobs are deemed to be positive, they can under certain conditions generate additional stress for staff especially as companies practicing HVFP strategies also require additional 'commitment' from their employees. This is manifested in requirements such as: greater flexibility in allocating workers' time on the line, considerable use of multitasking and multiskilling, increased flexibility in the scheduling of overtime and the reorganization of shifts to ensure that factories and machines produce goods for the maximum time possible within regulatory limits. Critics therefore suggest that such forms of production and work organization intensify the pace of work and are characterized by new and more subtle methods of control, exploitation and surveillance, intensification of the labour process and stress on workers (Okamura and Kawahito, 1990). A supervisor at Nissan's Washington factory in northeast England commented that in interviewing potential shopfloor workers: 'We lay it on the line that it's hard work, that they probably haven't ever worked as hard before' (reported in Tighe, 1998). Consequently, the intensive pace of work leads to physical injuries, such as repetitive strains and musculoskeletal disorders (Leslie and Butz, 1998), although the need to maintain quality standards and productivity levels creates psychological stress for those who occupy such jobs - and people often consider themselves fortunate to do so in regions blighted by unemployment and a prevalence of low wage, precarious jobs.

In the global 'South', the proliferation of sweatshops in a range of consumer goods industries, with workers working long hours in poorly lit and poorly ventilated environments, often amidst noxious materials, and with little autonomy or control over their pace of work, also raises serious questions about the health and safety of workers and about the use of child labour (recognized, for example, in corporate social responsibility campaigns in the 'North' to improve things in the 'South': for example, see Hughes, 2004, 2006). There are widespread problems because of the use of polluting materials and processes in many industrializing parts of the 'South' (see, for example, Engardio, 2007; Walker and Buck, 2007), in part linked to relocating polluting processes there from parts of the 'North', conjuring up images of the 'dark satanic mills' of the early stages of capitalist industrialization in the United Kingdom (Thompson, 1969). By way of illustration, we can consider the case of Schenzen which parallels many of the problems facing industrialized towns during the industrial revolution over a century ago in the 'North'. Schenzen is a 'boom town' in southern China, and has been a major centre of capital accumulation 
in the first decade of the twenty first century. It has become famous for the production of toys, Christmas ornaments and artificial trees for western markets. However, there is a darker side to this growth as the health of workers has been damaged due to them having to work with poisonous materials:

in the toy factories the workers have to deal with poisons every day. A lot of Christmas ornaments are made with special glues and many of the factories refuse to pay for protective equipment.

(August, 2002, p. 11)

In factories producing computers and related equipment in the Pearl River delta of China, workers are frequently exposed to dangerous chemicals (CAFOD, 2004). Often workers - including those who are single young women drawn to factory work from rural areas - live in accommodation that is at best basic and also poses threats to health and well-being (for example, see Lynch, 2007).

In parts of both the 'North (for example, northeast England, Brandenburg in Germany and Cape Breton in Canada) and 'South' (such as Bangalore in India) the proliferation of back offices, business process and call centres - the service sector equivalent of Taylorist manufacturing branch plants - has brought new forms of risk to the health of those employed in them. These are primarily risks linked to problems of mental ill-health as a result of the stress of working in closely monitored environments, in which the productivity of individual workers is closely monitored via sophisticated computerized algorithms and those that fail to meet the required targets know only too well that they are at risk of losing their job in places in which others are more than willing to take them (Hudson, 2006).

Secondly, the restructuring of agriculture over parts of the 'South' away from subsistence-based agricultural production for domestic consumption to focus on cash - crop production oriented to the export markets of the 'North' has resulted in a reduction of food for domestic consumption. This has resulted from a restructuring of agricultural production systems away from subsistence to cash - crop production, thereby moving the agricultural system away from production for domestic consumption to producing a range of 'exotic' fruits, vegetables and flowers for sale in the markets of the 'North' and more latterly to producing crops as a source of biofuels. Often such changes have resulted from pressures from international organizations such as the World Bank and its structural adjustment programmes - and as such are coloured with a strong neo-colonial hue that echoes a colonial past. As a result, malnutrition, famine and starvation, already rife over much of the global 'South' $-50 \%$ of the world's population are chronically malnourished and the vast majority of them are resident in the 'South' - have been further exacerbated. 
Thirdly, there are increased risks to health and well-being because of loss of work and worklessness, especially in parts of the 'North', as a result of the global flight of industrial capital. This has important effects on the mental and physical health on those who lost their former jobs and cannot get new waged work, increasing the risks of new forms of ill-health. The physically demanding and dangerous nature of work in industries such as coal mining, steel, shipbuilding and heavy engineering meant that they, and the areas in which they were concentrated, were traditionally associated with high levels of poor health arising from occupationally and industrially specific illnesses (for example, cancers and lung and respiratory diseases) as well as the general 'wear and tear' on bodies subjected to continuously working in strenuous jobs in difficult conditions reflected in musculoskeletal conditions and industrial injuries (for example, see Walsh et al, 2008). This is not without irony, as old and new combine in 'wicked' ways. On the one hand, there are the continuing residual negative health effects of working in industries such as coal mining, steel and shipbuilding. Added to this, living in derelict industrial landscapes, surrounded by the decaying remains of factories and industrial facilities on brownfield sites, has a disproportionately deleterious effect on the health and well-being of local communities. ${ }^{3}$ In addition, the 'lifestyle' choices made in many of these areas around alcohol and tobacco consumption have also compounded the deleterious effects of the wider economic and social environment. On the other hand, these issues are also overlaid by new problems of poor health and illbeing that result from an absence of waged work in environments that continue to display the polluting effects of industrial collapse and decay. Thus, in addition to the legacy of poor physical health as a result of working, people now suffer the effects of poor mental health and ill-being because of a lack of work and the consequences that this has for concepts of identity and selfworth. This downward spiral in terms of poor health also generates considerable task demands on the healthcare system which, as a result of the level of demand and the lack of tax related revenue within the area, may not provide the quality of service experienced in other, more affluent areas.

Fourthly, large-scale industrial development in the 'South' is typically associated with internal inter-regional and rural to urban migration on an unprecedented scale, most recently experienced in China. The result of this influx of people is that the scale of urbanization is reaching new levels (Walker and Buck, 2007), with a range of devastating consequences for the natural environment and human health. In many cases, the influx of people cannot be accommodated within planned housing schemes and therefore it results in the development of shanty 'towns' - with their associated problems of sanitation, poor environmental conditions and disease. Even where there is a welldeveloped planned housing scheme, the sheer volume of people moving into urban areas becomes problematic. As the urban environment becomes contaminated with a variety of pollutants, then public health is placed at risk 
because of booming industrial production, surging demand for electricity produced from carbon fossil fuels and major changes to lifestyle and consumption patterns, especially the growth of private car ownership. This has had widespread effects on public health as atmospheric pollution increases and potable water supplies are threatened (most spectacularly in China but by no means only there; for example, see Engardio, 2007). The unwanted environmental consequences of economic growth and industrialization remain heavily localized, between and within countries; pollution is time/space specific (noting, of course, that intergenerational effects are possible), impacting unevenly on spaces in which people live and work, on their health and wellbeing, and on death rates.

Fifthly, the (re-)location of 'risky' and highly polluting plants to parts of the 'South' and some parts of peripheries in the 'North' can endanger health and well-being. As the public understanding of the risks of polluting production has increased, then the expressed concern about these issues has also increased which has generated particular political conflicts at the local level (see, for example, Smith, 1990, 1991). Whereas the pollutant effects of some activities (for example, mining) are necessarily localized, companies engaged in other activities have greater freedom of locational choice. As such, they can site polluting industries in spaces of least resistance - from parts of the global 'South' to peripheral regions and inner cities in the 'North'. For example, Chicago's southeast side is plagued by numerous pollutant industries, commercial hazardous waste landfills and toxic waste dumps. Consequently, it has one of the highest rates of incidence of cancer in the United States (Bullard, 1994, pp. 279-80). In Sydney, Nova Scotia, the tar ponds - the legacy of the nowclosed steelworks - sit in the middle of the built up area, surrounded by signs warning people to keep out. The site - 'the most polluted site in north America' (Lotz, 1998, p. 167) - is extremely hazardous because of high concentrations of PCBs. Times Beach, Missouri, was irreparably contaminated by dioxin, a by-product of manufacturing antiseptic hexachlorophene (Calton, 1989). Although such events are comparatively rare they are not unknown in the internal peripheries of the 'North'.

In sharp contrast, such events are only too common over much of the industrializing cities and regions of the 'South'. As popular environmental awareness of the risks to health of polluting industries grew in the global 'North', in the global 'South' ruling élites and national states unashamedly prioritized and continue to prioritize - economic growth and employment over the natural environment and human health and well-being. Consequently, companies have been able to deploy dangerous working practices and polluting production technologies that are inadmissible within workplaces elsewhere. For example, in December 1984, 5 tons of poisonous methyl isocyanate gas leaked from the Union Carbide of India Ltd pesticides plant in Bhopal, killing more than 3000 people and injuring tens of thousands (see, for example, Hazarika, 
1987; Shrivastava, 1987; Smith and Sipika, 1993; Lapierre and Moro, 2002). By 1999 , the death toll exceeded $6000,{ }^{4}$ with substantial, and in some locations severe, pollution of land and drinking water supplies from heavy metals and organic contaminants. Residents of these areas are exposed to the risks of hazardous chemicals on a daily basis. There are many more examples of accidents at work leading to deaths, albeit on a less dramatic scale. For example, in 2003, over 30 workers were killed and 140 injured in an explosion at a fireworks factory in Wangkou, north of Beijing in China.

An alternative to exporting polluting industries is to export their pollutants, either deliberately or inadvertently into the largely unregulated global commons of the atmosphere and oceans (German Advisory Council on Global Change, 2002). In other cases, waste products are exported in different forms, deliberately targeting selected peripheral spaces as destinations. For example, Yearley (1995) reported that Kassa Island, off the coast of Africa, became the recipient of highly polluted incinerator ash from power stations in Philadelphia. Over a decade later, Houveld (2006) reported that a Greekregistered ship, chartered by a Dutch company, had discharged several hundred tons of highly toxic wastes, a poisonous mix of petrol wastes and cleaning agents, from its tanks at Abidjan, in the Ivory Coast. The sludge was then taken away by a local company, and dumped at 10 sites around Abidjan. This led to thousands of people being hospitalized and several deaths.

Export of wastes can be problematic for exporters, however, as the impacts of pollution may return to blight the health and well-being of people living in their spaces of origin. For example factories relocated from the United States into the maquiladora border zone in Mexico in response, inter alia, to less stringent environmental regulations there subsequently exported air pollution, sewage and contaminated food back to the United States as 'ecological havoc recognizes no boundaries' (George, 1992, p. 6). It is, however, important to keep a sense of proportion and keep the issue of pollution in its proper perspective in terms of health and well-being, as ceasing to produce all toxins, hazardous wastes and radioactive materials would have disastrous consequences for public health and the well-being of millions of people (Harvey, 1996, p. 400). Such changes would and should be powerfully contested. The issue therefore becomes one of debate and accommodation rather than the extremes of unfettered pollution or a total ban.

Finally, the provision of health care services via the market, allied to the introduction of pseudo-market criteria within the remaining public health sector, has increased inequalities in access to health care and in health outcomes. This has increased the risks of poor health and ill-being to many - not least refugees who lack both the money to buy health care and the political rights to access it via citizenship. At the same time, the greatly increased 
scale of the movement of people is increasing the risks of global pandemics of infectious diseases. Growing numbers of frequent international travellers may magnify the transmission of infectious diseases such as SARS and avian flu (Commission on the Macroeconomics of Health, 2001, p. 76). Although this may be true, there are other effects on health and well-being as a result of the growth in international migration. In many parts of Europe for example, health care systems have come to rely on immigrants from other parts of the world. The migration to Europe of doctors, nurses and medical professionals from parts of Africa, the Caribbean and Asia is well-established, often linked to former colonial ties. The recently growing tendency for countries in the 'North' selectively to use those in the 'South' as sources of skilled labour, to meet labour shortages in critical occupations in health care via immigration, has both added to and generalized this pattern of migration flows. Often, therefore, these migratory movements have led to accusations of promoting a neocolonial 'brain drain' of talented people from countries such as Egypt, India or Sri Lanka (although this is more a question of reinforcing existing trends rather than establishing wholly new ones as these countries have long-established roles as providers of skilled international migrant labour). In 20 African countries, more than $35 \%$ of nationals with a University education are living abroad (Commission on Macroeconomics and Health, 2001, pp. 75-6). The migration abroad of medically trained staff is particularly problematic as this has a massive effect on the performance of health care systems in 'Southern' countries that are already over-burdened with problems around disease and general public health. This registers an enduring developmental dilemma. Although enabling the individuals involved to enhance their health, well-being and lifestyle and acquire more highly remunerated employment within globalized labour markets for highly qualified labour, the corollary is that the origin areas lose people with skills that they can ill-afford to lose (not least, in health care), with important developmental implications and implications for the health and well-being of those who must of necessity remain in those origin areas.

The greatest problems of ill-health and ill-being are to be found in countries with 'failed' or 'fragile states', with the lowest per caput GDP and incomes and often further depleted by the out-migration of qualified personnel. Nearly half of all the children who die before the age of 5 years are born in these 'fragile states', with child mortality almost two and a half times higher than in other poor countries. Even in cases where internal (or external) conflict as such is not an issue, there are key questions of political and policy choices and priorities, which affect the distribution of health outcomes: in short, is the priority guns or health care? Is the priority production of flowers for export or food for domestic consumption? In a situation in which a majority of the world's population are under-nourished and lack a sufficient calorie intake to reproduce the body healthily, it seems odd that food production is anything other than 
number one priority. Are taxation and income redistributive policies progressive or regressive? There is evidence that some - as many as 50 - governments in developing countries impose high tariffs and taxes on imported drugs as a way of raising revenue, off-setting the attempts to persuade pharmaceutical companies to provide drugs at lower cost to these countries and the decision by the WTO in 2003 to allow poor countries which lacked a domestic pharmaceuticals industry and pharmaceuticals production capacity to arrange with other countries to produce cheap generic versions of drugs still protected by patents. As a result, the prices of drugs are driven up and many people in these countries cannot afford them. Equally, sales taxes on items such as food invariably serve to reduce food consumption among the poorer sections of society and thereby increase their vulnerability to illness and disease (Bate et al, 2005). In short, a range of economic and social policy choices have critical effects on mortality rates, health outcomes and the quality of life and wellbeing of those who survive.

\section{Conclusions}

With around half of the world's population already malnourished, there is no doubt that many people already suffer chronic ill-health and ill-being. Many more are at risk of suffering even more as a result of the combined effects of changing political - economic priorities and the deliberate deepening of uneven development that has been an integral part of the neo-liberal 'project'. The extent to which there is an appreciation of the effects of neo-liberal globalization in increasing risks to public health remains much less certain. Beyond this, however, there is now a growing recognition of the deleterious effects of human activities on climate change and the socio-ecological system more generally and the further risks that these pose to health and well-being. Although there is a growing acknowledgment that human activity is accelerating the rate of climate change, and that this poses growing risks to public health, albeit unevenly distributed across the globe, there is nothing resembling an effective consensus to do something radical to ameliorate the risks this poses to health and well-being - indeed survival. There is a continuing naive and, in its own way, touching belief that somehow human ingenuity will prevail and a technological fix will emerge (largely around such issues as: safe nuclear power, carbon capture, mass produced cheap renewable energy, a hydrogen-based economy and the like), thereby averting the need for radical changes to economy, society and lifestyles. It remains an open question as to whether such technological innovations will in fact emerge and even more so if they will emerge in time to avoid catastrophic climatic changes. It is by no means certain, therefore, that these challenges can be tackled effectively and even more so if this can be done in a timely fashion and in a way that increases environmental and socio-spatial justice 
rather than further widen the gap between those who enjoy good health and well-being and those condemned to a life of ill-being, poor health and premature death on the margins.

\section{Acknowledgements}

This is a revised and extended version of a paper first presented to the Risk and Security Management Forum Summer Seminar Programme, Goodwood Park Hotel, 9-10 July. Thanks to participants there for constructive comments. Denis Smith subsequently commented constructively and at some length and I have sought to accommodate his suggestions in this version. However, the usual disclaimers apply.

\section{Notes}

1 In the remainder of the paper, I draw a contrast, but also note some similarities, between changes in the global 'North' and 'South'. I do so partly for ease of exposition, partly because there are significant developmental differences between 'North' and 'South'. At this point, however, I want to enter a qualification, to recognize that this binary dichotomy is an over-simplification. The global movements of capital and people have led to elements of the 'South' locating in the 'North'; and vice versa. For example, many of the successful urban and regional economies of the 'North' depend critically on corporeal movements of migrant workers from the 'South'. Again, with the rise of the Chinese and Indian economies (Engardio, 2007; Walker and Buck, 2007) and the acquisition of major companies in the 'North' by those based in the 'South' (for example, of Corus by Tata and Acelor by Mittal), the meaning of these two terms is becoming increasingly blurred and relations between 'North' and 'South' increasingly complicated as new patterns of combined and uneven development emerge. It is also worth noting, however, that because capitalist development in inherently combined and uneven, there is no guarantee that China and India will continue to be centres of rapid economic growth and capital accumulation as the accumulation process is chronically one that erodes the place-based conditions of its success.

2 For example, the World Bank focuses on 30 'low-income countries under stress' (World Bank, 2004), whereas the UK Government's Department of International Development recognizes 46 countries in a broader list of 'fragile countries', which contain some 900 million inhabitants, or $14 \%$ of the global population (DiFD, 2005). Between 1990 and 2002, the incomes of these states were stagnant (compared with a 1.2\% annual growth in other developing countries - hardly spectacular but at least growth).

3 Professor Paul Symes, English Partnerships, February 2008 - I am grateful to my colleague Dr Karen Johnson in the School of Engineering at Durham for this information

4 The death toll from this accident has always been the subject of some debate. The tradition of burning the bodies soon after death, the lack of an effective census of the people living in the shanty towns and the impact of latent deaths have all contributed to this uncertainty.

\section{References}

Adler, N.E. and Newman, K. (2002) Socioeconomic disparities in health: Pathways and policies. Health Affairs 21: 60-76.

August, O. (2002) Workers abused in sweatshops of China's economic miracle. The Times, 24 December.

Basle Action Network (BAN). (2003) Needless Risk: The Bush Administration's Scheme to Export Toxic Waste Ships to Europe. Basle: BAN, p. 63. 
Bate, R., Trend, R. and Urbach, J. (2005) Taxed to Death. Washington, DC: AEI-Brookings Joint Centre for Regulatory Studies.

Beck, U. (1992) Risk Society. Towards a New Modernity. London: Sage.

Benach, J. and Muntaner, C. (2007) Precarious employment and health: Developing a research agenda. Journal of Epidemiology and Community Health 61: 276-277.

Benach, J., Muntaner, C., Benavides, F.G., Amable, M. and Jodar, P. (2002) A new occupational health agenda for a new work environment. Scandinavian Journal of Work, Environment and Health 28: 191-196.

Benavides, F.G., Benach, J., Diez-Roux, A.V. and Roma, C. (2000) How do types of employment relate to health indicators? Findings from the second European survey on working conditions. Epidemiology and Community Health 54: 494-501.

Buerk, R. (2006) Breaking Ships. New York: Chamberlain Books.

Bullard, R. (ed.) (1994) Unequal Protection: Environmental Justice and Communities of Color. California: San Francisco.

CAFOD. (2004) Clean up Your Computer: Working Conditions in the Electronics Sector. London: CAFOD.

Calton Jr., W.R. (1989) Cargoism and Technology and the Relationship of these Concepts to Important Issues such as Toxic Waste Disposal Sites. In: D. Peck (ed.) Psychosocial Effects of Hazardous Toxic Waste Disposal on Communities. Springfield: Illinois, Charles C Thomas, pp. 99-117.

Commission on Macroeconomics and Health. (2001) Macroeconomics and Health: Investing in Health for Economic Development. Geneva: WHO.

Damette, F. (1980) The Regional Framework of Monopoly Exploitation. In: J. Carney, R. Hudson and J. Lewis (eds.) Regions in Crisis: New Perspectives in European Regional Theory. Beckenham: Croom Helm, pp. 76-92.

de Vries, J., Michielson, H.J. and van Hech, G.L. (2003) Assessment of fatigue among working people: A comparison of six questionnaires. Occupational and Environmental Medicine 60(Supplement 1): i10-i15.

Department of International Development. (2005) Why we Need to Work More Effectively in Fragile States. London: DiFD.

Dooley, D., Rook, D. and Catalano, R. (1987) Job and non-job stressors and their moderators. Journal of Occupational Psychology 60: 115-132.

Engardio, P. (ed.) (2007) CHINDIA: How China and India Are Revolutionizing Global Business. New York: McGraw Hill.

George, S. (1992) The Debt Boomerang: How Third World Debt Harms Us All. London: Pluto Press.

German Advisory Council on Global Change. (2002) Charging the Use of Global Commons. Berlin: WBGU.

Harvey, D. (1996) Justice, Nature and the Geography of Difference. Oxford: Blackwell.

Hazarika, S. (1987) Bhopal. The Lessons of a Tragedy. New Delhi: Penguin Books (India).

Hirst, P. and Thompson, G. (1995) Globalization in Question. Cambridge: Polity.

Houveld, K. (2006) Toxic fumes unleash panic in the Paris of Africa. Sunday Times, 16 September: p. 26.

Hudson, R. (2001) Producing Places. New York: Guilford.

Hudson, R. (2006) From carboniferous capitalism to call centres: The case of Cape Breton. Research Paper 2, Centre for the Study of Cities and Regions, Durham University, 47 pp., http://www.dur.ac.uk/resources/cscr/papers/researchpaper2.pdf. 
Hughes, A. (2004) Accounting for Ethical Trade: Global Commodity Networks, Virtualism and the Audit Economy. In: A. Hughes and S. Reimer (eds.) Geographies of Commodity Chains. London: Routledge, pp. 215-232.

Hughes, A. (2006) Learning to trade ethically: Knowledgeable capitalism, retailers and contested commodity chains. Geoforum 37: 1007-1019.

International Organisation for Migration. (2003) Annual World Migration Report, http://www.iom.int, accessed 11 June 2005.

Lapierre, D. and Moro, J. (2002) Five Past Midnight in Bhopal. New York: Warner Books.

Leslie, D. and Butz, D. (1998) 'GM suicide': Flexibility, space and the injured body. Economic Geography 74: 360-378.

Lotz, J. (1998) The Lichen Factor: The Search for Community Development in Canada. Sydney: UCCB Press.

Lynch, C. (2007) Juki Girls, Good Girls: Gender and Cultural Politics in Sri Lanka's Global Garment Industry. Ithaca: Cornell University Press.

Muntaner, C., Nieto, F.J., Cooper, L., Meyer, J. and Szklo, M. (1998) Work organization and atherosclerosis: Findings from the ARIC study. American Journal of Preventative Medicine 14: 9-18.

O’Brien, R. (1992) Global Financial Integration: The End of Geography. London: Pinter.

Okamura, C. and Kawahito, H. (1990) Karoshi. Tokyo: Mado Sha.

Sen, A.K. (1983) Poverty and Famines: An Essay on Entitlement and Deprivation. Oxford: Oxford University Press.

Shrivastava, P. (1987) Bhopal. Anatomy of a Crisis. Cambridge, MA: Ballinger Publishing Company.

Smith, D. (1990) Corporate power and the politics of uncertainty: Risk management at the Canvey Island complex. Industrial Crisis Quarterly 4: 1-26.

Smith, D. (1991) The Kraken wakes - the political dynamics of the hazardous waste issue. Industrial Crisis Quarterly 5: 189-207.

Smith, D. and Sipika, C. (1993) Back from the brink - post-crisis management. Long Range Planning 26: 28-38.

Thompson, E.P. (1969) The Making of the English Working Class. Harmondsworth: Penguin.

Tighe, C. (1998) Nissan shows the way in the drive to boost productivity. Financial Times, 24 November.

Walker, R. and Buck, D. (2007) The Chinese road. New Left Review 46: 39-68.

Walsh, D., Taulbut, M. and Hanlon, P. (2008) The Aftershock of Deindustrialisation: Trends in Mortality in Scotland and Other Parts of Post-Industrial Europe. Glasgow: Centre for Population Health and NHS Scotland, p. 260.

Wegge, J., van Cick, R., Fisher, R., Wecking, C. and Moltzen, K. (2006) Work motivation, organizational identification and well-being in call centre work. Work and Stress 20: 60-83.

World Bank. (2004) Evaluation of World Bank support to low-income countries under stress, www.worldbank.org.

Yearley, S. (1995) Dirty Connections: Transnational Pollution. In: J. Allen and C. Hamnett (eds.) A Shrinking World? Oxford: Oxford University Press, pp. 143-182. 